\title{
CARROT SEED COATING WITH BACTERIA FOR SEEDLING PROTECTION FROM GRASS GRUB DAMAGE
}

\author{
D.A.WRIGHT, J. SWAMINATHAN, M. BLASER and T.A. JACKSON \\ Biocontrol and Biosecurity Group, AgResearch, PO Box 60, Lincoln \\ Corresponding author: jayanthi.swaminathan@agresearch.co.nz
}

\begin{abstract}
Carrot seedlings are susceptible to damage from grass grub larvae. The biological control bacterium, Serratia entomophila, was applied to the surface of carrot seeds via pelleting or as a biopolymer seed coating and the activity against grass grubs determined in pot trials. Seedling mortality caused by grass grub larvae was significantly reduced $(\mathrm{P}<0.05)$ in two trials from 88 and $64 \%$ in untreated pots to 26 and $13 \%$ in pots containing pelleted seed and 7 and $16 \%$ in pots containing biopolymer-coated seed. Shelf life studies showed formulations were stable at $4^{\circ} \mathrm{C}$ for at least eight weeks and for two weeks at $20^{\circ} \mathrm{C}$, after which cell viability decreased over time. Bioassay results showed little difference between the two treatments, despite a higher concentration of bacteria on the biopolymer-coated than the pelleted seeds. The potential of seed coating as a delivery mechanism for biocontrol agents has been demonstrated and future possibilities are discussed.

Keywords: grass grub, biological control, Serratia entomophila, seed coating, biopolymer.
\end{abstract}

\section{INTRODUCTION}

The New Zealand grass grub (Costelytra zealandica (White)) (Scarabeidae: Melolonthinae) is an important pasture pest in New Zealand. Although not generally considered a major pest for horticultural crops, grass grub may cause serious damage in crops such as carrot and swede particularly when planted in areas recently converted from pasture.

A non-spore forming bacterium of the Enterobacteriaceae, Serratia entomophila, is produced commercially as a granular formulation, Bioshield ${ }^{\mathrm{TM}}$ grass grub for the control of grass grub in New Zealand pastures (Townsend et al. 2004) and may be beneficial for crops such as carrot. Current formulations are designed for large scale, blanket application (Townsend et al. 2004) and while this approach may be applied to horticultural crops, the targeted application of $S$. entomophila by incorporation into seed coatings may reduce the quantities of bacteria required for effective control while allowing application at the time of planting using existing machinery (Taylor \& Harman 1990).

The purpose of this trial was to evaluate the potential of seed coatings containing live bacterial cells of $S$. entomophila to reduce carrot seedling mortality by grass grubs under controlled conditions.

\section{MATERIALS AND METHODS}

\section{Primary ingredients and storage shelf life studies}

Bacteria were incorporated onto the seed coating by pelleting (Taylor \& Harman 1990) or biopolymer coating (NZ Patent No. 506484). The number of S. entomophila colony forming units (CFUs) per gram of seed was determined by dilution plate enumeration on caprylate thallous agar (CTA) (O'Callaghan \& Jackson 1993). Samples were incubated at $4^{\circ} \mathrm{C}$ and $20^{\circ} \mathrm{C}$ and the number of CFU was determined at fortnightly intervals to establish shelf life potentials. 


\section{Bioassay design}

A completely randomised, $3 \times 2$ factorial design, 6 replicate pot trial was set up. Thirty-six $150 \mathrm{~mm}$ diameter pots were filled with approximately $1250 \mathrm{~g}$ of unsterilised Wakanui silt loam (moisture content $22 \%$ ) and randomly allocated to treatment groups.

Seventy-two late $2^{\text {nd }}$ instar grass grub larvae were collected from the AgResearch Lincoln farm and fed small pieces of carrot overnight to ensure that they were actively feeding. Four grass grub larvae per pot were added to 18 pots and allowed to burrow into the soil prior to planting. Pots were planted with either biopolymer-coated hybrid seed, pelleted hybrid seed or untreated hybrid seed ( 24 seeds/pot) and covered with wet newspaper until germination when the newspaper was removed. The 18 pots without grass grub larvae were planted with corresponding seed for negative control. The pots were placed in an unheated glasshouse and watered regularly to maintain soil moisture at the surface of the pot. Due to high temperatures in the glasshouse, after one week they were moved to a $23^{\circ} \mathrm{C}$ temperature controlled room and placed under a F58W GROLUX UV lamp for the remainder of the trial to avoid extremes of temperature. The trial was repeated under the controlled conditions 1 week later and both trials were run concurrently. Seven days post-seeding all pots were given $177 \mathrm{ml}$ water to simulate a $10 \mathrm{~mm}$ rainfall event and this was repeated at seven day intervals. Pots were observed weekly and the number of seedlings in each was recorded. Four (Trial 1) or five (Trial 2) weeks post-seeding the larvae were recovered from the pots and placed into a feeding test after which the level of $S$. entomophila infection was determined using techniques described in O'Callaghan et al. (1992).

Seedling emergence percentages for each week of the trial were statistically analysed as a $3 \times 2$ factorial using analysis of variance.

\section{Coating density and shelf life}

\section{RESULTS}

The biopolymer-coated seed formulation had an initial concentration of $8.72 \times 10^{9} \mathrm{CFU} / \mathrm{g}$ with 323 seeds/g, while the pelleted seed had an initial concentration of $8.50 \times 10^{4} \mathrm{CFU} / \mathrm{g}$ with 57 seeds/g (equivalent to $2.70 \times 10^{7}$ and $1.49 \times 10^{3}$ bacteria/seed respectively). The biopolymer-coated formulation was relatively stable at $4^{\circ} \mathrm{C}$ for at least eight weeks. At $20^{\circ} \mathrm{C}$ the biopolymer-coated formulation remained stable for two weeks followed by the gradual loss of cell viability (Fig. 1). Similar results were obtained for the pelleted seed (data not shown).

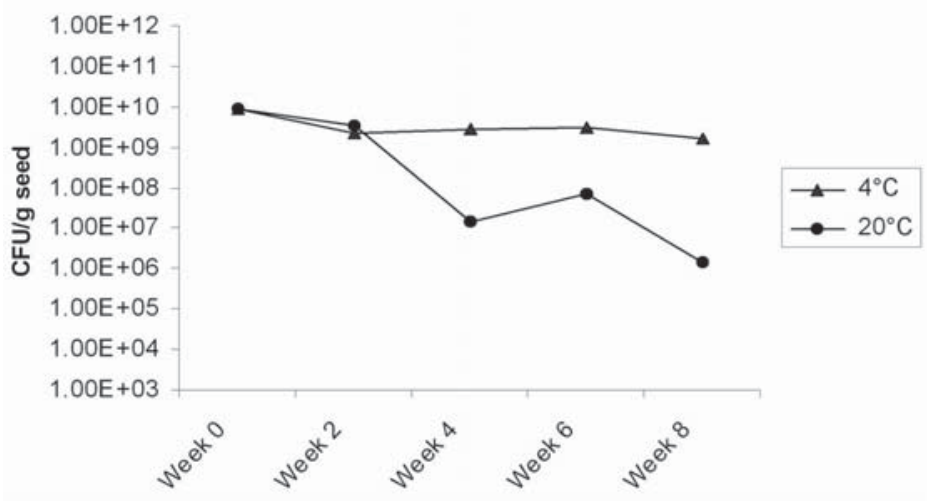

FIGURE 1: Number of bacterial CFU/g biopolymer-coated carrot seed monitored for 8 weeks at $4^{\circ} \mathrm{C}$ and $20^{\circ} \mathrm{C}$. 


\section{Bioassay - seedling number}

The number of untreated carrot seedlings was significantly reduced $(\mathrm{P}<0.05)$ in the presence of grass grub larvae when compared to $S$. entomophila-coated seed and untreated pots without larvae from weeks 1 and 2 onwards in Trials 1 and 2 respectively (Tables $1 \& 2$ ). The mean reduction in the number of carrot seedlings from untreated seed in pots containing larvae relative to untreated seed in pots with no larvae after four weeks was $88 \%$ (Trial 1) and 64\% (Trial 2). The mean reduction in carrot seedling numbers due to grass grub larvae after four weeks was 26\% (Trial 1) and 13\% (Trial 2) for the pelleted seed, and 7\% (Trial 1) and 16\% (Trial 2) for the biopolymer-coated seed. Biopolymer-coated seed mortality caused by grass grub larvae was significantly lower than with pelleted seed at weeks 3 and $4(\mathrm{P}<0.05)$ in Trial 1 but this was not observed in the second trial. In the absence of grass grub larvae there were slightly more seedlings in the coated seed groups than the untreated seed in both trials, although this was not always significant (Tables 1 \& 2).

TABLE 1: Mean seedling emergence (\%) for the untreated, pelleted and biopolymer-coated $(\mathrm{Bp})$ carrot seeds in pots with or without grass grub larvae in Trial 1.

\begin{tabular}{lcccc}
\hline & Week 1 & Week 2 & Week 3 & Week 4 \\
\hline Pelleted + larvae & 67.4 & 66.7 & 67.4 & 67.4 \\
Bp +larvae & 63.2 & 71.2 & 80.6 & 78.5 \\
Untreated +larvae & 47.2 & 32.5 & 13.3 & 9.2 \\
& & & & \\
Pelleted -larvae & 88.2 & 85.4 & 88.9 & 91.7 \\
Bp -larvae & 76.4 & 81.2 & 85.4 & 84.0 \\
Untreated -larvae & 73.6 & 75.7 & 75.7 & 75.7 \\
& & & & \\
LSD (P=0.05) & 14.6 & 11.7 & 10.9 & 10.5 \\
Significance of contrasts: & & & & \\
Larvae (L) m.e. $^{2}$ & $* * *$ & $* * *$ & $* * *$ & $* * *$ \\
Seed treat (T) m.e. & $* *$ & $* * *$ & $* * *$ & $* * *$ \\
Pell vs Bp (M) m.e. & $\mathrm{ns}$ & $\mathrm{ns}$ & $\mathrm{ns}$ & $\mathrm{ns}$ \\
L x T interaction $^{\text {L x M interaction }}$ & $\mathrm{ns}$ & $* * *$ & $* * *$ & $* * *$ \\
\hline
\end{tabular}

${ }^{1} \mathrm{~ns}=$ not significant; $*=\mathrm{P}<0.05 ; * *=\mathrm{P}<0.01 ; * * *=\mathrm{P}<0.001$.

${ }^{2}$ m.e.=main effect.

\section{Bioassay - grass grub larvae recovery}

There was a low grass grub larvae recovery rate in both trials. In Trial 1 a higher total number of larvae was recovered from untreated seed pots (12) than pelleted (1) and biopolymer-coated pots (2). Table 3 shows the number of larvae recovered from Trial 2 pots after five weeks. Again, more were recovered from the untreated seed pots than the treated pots. 
TABLE 2: Mean seedling emergence (\%) for the untreated, pelleted and biopolymer-coated $(\mathrm{Bp})$ carrot seeds in pots with or without grass grub larvae in Trial 2.

\begin{tabular}{|c|c|c|c|c|c|}
\hline & Week 1 & Week 2 & Week 3 & Week 4 & Week 5 \\
\hline Pelleted +larvae & 3.6 & 79.9 & 75.7 & 76.4 & 75.0 \\
\hline Bp +larvae & 17.4 & 73.6 & 75.0 & 74.3 & 77.1 \\
\hline Untreated +larvae & 4.9 & 43.1 & 36.8 & 27.8 & 27.8 \\
\hline Pelleted -larvae & 45.8 & 86.1 & 87.5 & 88.2 & 88.2 \\
\hline Bp -larvae & 24.3 & 85.4 & 86.8 & 88.2 & 88.2 \\
\hline Untreated -larvae & 16.7 & 77.8 & 77.1 & 77.1 & 76.4 \\
\hline $\operatorname{LSD}(\mathrm{P}=0.05)$ & 25.6 & 11.8 & 13.6 & 13.2 & 13.1 \\
\hline \multicolumn{6}{|c|}{ Significance of contrasts: ${ }^{1}$} \\
\hline Larvae (L) m.e. ${ }^{2}$ & ns & $* * *$ & *** & $* * *$ & *** \\
\hline Seed treat $(\mathrm{T})$ m.e. & $*$ & $* * *$ & $* * *$ & $* * *$ & $* * *$ \\
\hline Pell vs $B p(M)$ m.e. & ns & ns & ns & ns & ns \\
\hline $\mathrm{L} \times \mathrm{T}$ interaction & ns & $* *$ & $* *$ & $* * *$ & $* * *$ \\
\hline $\mathrm{L} \times \mathrm{M}$ interaction & ns & ns & ns & ns & ns \\
\hline
\end{tabular}

${ }^{1}$ ns=not significant $; *=\mathrm{P}<0.05 ; * *=\mathrm{P}<0.01 ; * * *=\mathrm{P}<0.001$

${ }^{2}$ m.e.=main effect.

TABLE 3: Total numbers of grass grub larvae recovered from pots after five weeks in Trial 2.

\begin{tabular}{lcccc}
\hline Treatment & Healthy & Diseased & Dead & Total $^{1}$ \\
\hline Untreated & 6 & 0 & 2 & 8 \\
Pelleted & 1 & 0 & 4 & 5 \\
Biopolymer-coated & 0 & 1 & 2 & 3 \\
\hline
\end{tabular}

${ }^{1}$ A total of 24 grass grub larvae was added for each seed type.

\section{DISCUSSION}

This trial has demonstrated that carrot seeds coated with formulations containing S. entomophila bacterial cells significantly reduce the damage caused to seedlings by grass grubs under the experimental conditions. In the field, plant and grub densities are likely to be significantly lower and future trials should be conducted to confirm the level of efficacy under conditions that more closely reflect commercial systems. While there was little difference in efficacy between the pelleted and biopolymer-coated seed, it is possible the higher bacterial loading of the biopolymer-coated seed may be advantageous under field conditions. Comparisons of the efficacy between the two treatments should be treated with caution as the production methods were different and the hybrid cultivar of the pelleted seed was different from that of biopolymer-coated seed. The biopolymercoated and untreated seed was the same cultivar and it was interesting to note the slightly higher germination rate of the coated seed in the absence of grubs. It is possible that the biopolymer coating or bacteria enhances plant growth and this aspect should be investigated further.

There was high grass grub mortality, even in untreated pots. Very high mortalities occurred where seeds had been treated with bacteria. In these treatments the germinating seedling may have attracted the larvae bringing them into close contact with the bacteria early in the experiment. This could have resulted in a cycle of disease and death within the experimental timeframe of 4-5 weeks. The high experimental mortality throughout was due to other causes. It is unlikely that natural diseases were involved as all grubs 
appeared healthy and were actively feeding prior to introduction to the pots and there were no indications of fungal, protozoan or bacterial infections other than amber disease, in grubs recovered at the end of the trial. Natural grass grub populations are regulated by density dependent aggressive interactions between larvae (East et al. 1981), and it is likely that mortality was due to these interactions, particularly when the high density (512 grubs $\left./ \mathrm{m}^{2}\right)$ is considered.

Soil temperatures may also have been a factor. While the temperature of the soil during the trial was within the range expected in the field during the second instar phase, third instars are generally found deeper where temperatures are lower and from February onward when soil temperatures are decreasing. The late second instars used in this trial were very close to third instar and it is possible this stage of development is susceptible to the elevated temperatures of the trial. Further investigations into grass grub damage to carrots are warranted, especially in crops planted from February onward that may be at risk of damage by the more prolifically feeding third instar stage.

This trial has demonstrated that the application of biological control agents via biopolymer seed coating is a viable mechanism for the control of pests. While the control of grass grub alone may have limited appeal to carrot growers, future applications might involve combinations of biologicals to control other important pest species such as carrot rust fly.

\section{ACKNOWLEDGMENTS}

The authors would like to acknowledge the assistance of Richard Townsend with larval collection, trial set up and discussion of results and Dave Saville for statistical advice, discussion of results and comment on the manuscript. Our thanks to Tim Chamberlain for encouragement and provision of carrot seeds.

\section{REFERENCES}

East R, King PD, Watson RN 1981. Population studies of grass grub (Costelytra zealandica) and black beetle (Heteronychus arator) (Colepotera:Scarabaeidae). New Zealand Journal of Ecology 4: 56-64.

O'Callaghan M, Jackson TA, Mahanty HK 1992. Selection, development and testing of phage-resistant strains of Serratia entomophila for grass grub control. Biocontrol Science and Technology 2: 297-305.

O'Callaghan M, Jackson TA 1993. Isolation and enumeration of Serratia entomophila - a bacterial pathogen of the New Zealand grass grub, Costelytra zealandica. Journal of Applied Bacteriology 75: 307-314.

Taylor AG, Harman GE 1990. Concepts and technologies of selected seed treatments. Annual Review of Phytopathology 28: 321-339.

Townsend RJ, Ferguson CM, Proffitt JR, Slay MWA, Swaminathan J, Day S, Gerard E, O'Callaghan M, Johnson VW, Jackson TA 2004. Establishment of Serratia entomophila after application of a new formulation for grass grub control. New Zealand Plant Protection 57: 310-313. 